Research Paper

\title{
Gene cloning, expression, and characterization of the Bacillus amyloliquefaciens PS35 lipase
}

\author{
Palanisamy Kanmani, Kuppamuthu Kumaresan, Jeyaseelan Aravind \\ Department of Biotechnology, Kumaraguru College of Technology, Coimbatore, India.
}

Submitted: September 25, 2014; Approved: March 5, 2015.

\begin{abstract}
Lipases are enzymes of immense industrial relevance, and, therefore, are being intensely investigated. In an attempt to characterize lipases at molecular level from novel sources, a lipase gene from Bacillus amyloliquefaciens PS35 was cloned, heterologously expressed in Escherichia coli DH5 $\alpha$ cells and sequenced. It showed up to $98 \%$ homology with other lipase sequences in the NCBI database. The recombinant enzyme was then purified from E. coli culture, resulting in a 19.41-fold purification with $9.7 \%$ yield. It displayed a preference for long-chain para-nitrophenyl esters, a characteristic that is typical of true lipases. Its optimum $\mathrm{pH}$ and temperature were determined to be 8.0 and $40^{\circ} \mathrm{C}$, respectively. The half-lives were $2.0,1.0$ and $0.5 \mathrm{~h}$ at $50^{\circ} \mathrm{C}, 60^{\circ} \mathrm{C}$ and $70{ }^{\circ} \mathrm{C}$, respectively. The metal ions $\mathrm{K}^{+}$and $\mathrm{Fe}^{3+}$ enhanced the enzyme activity. The enzyme displayed substantial residual activity in the presence of various tested chemical modifiers, and interestingly, the organic solvents, such as $n$-hexane and toluene, also favored the enzyme activity. Thus, this study involves characterization of $B$. amyloliquefaciens lipase at molecular level. The key outcomes are novelty of the bacterial source and purification of the enzyme with desirable properties for industrial applications.
\end{abstract}

Key words: $E$. coli $\mathrm{DH} 5 \alpha$, lipase properties, nucleotide sequencing, purification, recombinant enzyme.

\section{Introduction}

Lipases (triacylglycerol acylhydrolases EC. 3.1.1.3) are enzymes that typically catalyze the hydrolysis of longchain triacylglycerols by their action at oil-water interface. In addition to this hydrolytic reaction, they also catalyze reverse reactions of esterification, transesterification, and interesterification in non-aqueous environments. Substrate, stereo-, regio- and enantio- specificities, and chiral selectivity are certain unique attributes of lipases that make them industrially attractive. These properties are often exploited in the manufacturing of detergent formulations, synthesis of fine chemicals, pharmaceuticals, useful esters and peptides, food processing, paper manufacturing, degreasing of leather as well as in bioremediation (Hassan et al., 2006).

Bacillus sp., a family of Gram-positive bacteria, has been extensively investigated and used in a number of fields (Hirose et al., 2000; Tjalsma et al., 2000). Several members of this genus are nonpathogenic and easy to cultivate; they secrete key extracellular hydrolytic enzymes such as proteases, amylases, and lipases with remarkable thermostability and alkaline stability. Of particular significance are the lipases, which attract a great deal of attention owing to their unique protein sequences and rare biochemical properties (Chen et al., 2004; Olusesan et al., 2011).

Lipases have been purified and characterized from a number of Bacillus spp. including B. subtilis, B. coagulans, $B$. licheniformis, $B$. stearothermophilus, $B$. thermoleovorans, and B. cereus (Chakraborty and Raj, 2008; Chen et al., 2007; Kambourova et al., 2003; Kumar et al., 2005; Lee et al., 2001; Olusesan et al., 2011). Lipase-encoding genes from these species have also been cloned, sequenced and expressed in heterologous hosts (Nthangeni et al., 2001; Sabri et al., 2009; Sunna et al., 2002). Of these, B. subtilis has been the most intensely investigated source. Unlike the aforementioned species, the 
lipolytic activity of $B$. amyloliquefaciens has not been well reported, and hence this organism was chosen for cloning and expression studies. One drawback in the large-scale utilization of Bacillus lipases is their low level of expression, a limitation that could be overcome by employing recombinant DNA technology.

In this study, a novel lipolytic strain $B$. amyloliquefaciens PS-35 was used. Genomic DNA library of PS-35 was constructed in pUC18, which was used to transform Escherichia coli DH5 $\alpha$ cells. The transformed cells were screened for lipase activity and the best lipaseproducing clone was sequenced and analyzed. The recombinant lipase was purified and its properties were deduced, targeting key industrial applications of the enzyme.

\section{Materials and Methods}

\section{Chemicals}

All used chemicals were of analytical, molecular biology, or chromatographic grades as required. EcoR1, T4 DNA ligase, molecular weight markers, and Coomassie Brilliant Blue R-250 were from Aristogene Biosciences, India. Phenyl Sepharose CL-4B and Phosphocellulose PC-11 were from GE Life Sciences, UK. $p$-Nitrophenyl palmitate ( $p$-NPP) and bovine serum albumin were from Sigma Chemicals, USA. All bacteriological media were sourced from Hi-Media, India.

\section{Bacterial strains, plasmids, and culture media}

A novel strain of B. amyloliquefaciens designated as PS-35, which was previously isolated in our lab from poultry slaughterhouse effluent, possessing well-established lipase activity, and identified by 16S rRNA gene sequencing (GenBank Accession No. KJ000043), was used in the study. It was cultured at $35{ }^{\circ} \mathrm{C}$ in oil-supplemented glucose-yeast extract-peptone broth containing (per L) $20 \mathrm{~g}$ glucose, $10 \mathrm{~g}$ yeast extract, $10 \mathrm{~g}$ peptone, and $20 \mathrm{~mL}$ olive oil. Plasmid pUC18 was used as the cloning and expression vector. E. coli strain DH5 $\alpha$ cells, cultivated at $37{ }^{\circ} \mathrm{C}$ in Luria-Bertani (LB) broth containing (per L) $10 \mathrm{~g}$ tryptone, $5 \mathrm{~g}$ yeast extract, and $10 \mathrm{~g} \mathrm{NaCl}$, were used as gene cloning and expression systems.

\section{Cloning, expression, and sequencing of the lipase-encoding gene}

\section{Construction of PS-35 genomic DNA library in pUC18}

Isolation and purification of genomic and plasmid DNA, ligation, transformation, screening, and all other genetic manipulations were carried out according to the protocols suggested by Sambrook et al. (1989) and Sambrook and Russell (2001). For preparation of the insert DNA, genomic DNA was isolated from overnight grown culture of PS-35 according to phenol-chloroform extraction protocol. It was digested with the restriction endonuclease
EcoR1 and run on $0.8 \%$ agarose gel, and DNA fragments in $2-3 \mathrm{~kb}$ range were cut carefully from the gel and purified by the silica method. The pUC18 plasmid vector containing a unique EcoR1 site was prepared using the alkaline lysis method, digested, dephosphorylated with calf intestinal alkaline phosphatase, run on the agarose gel, and purified. The digested pUC18 DNA was then ligated with fragments of PS-35 genomic DNA using T4 DNA ligase.

\section{Transformation of E. coli DH5 $\alpha$ cells}

E. coli $\mathrm{DH} 5 \alpha$ cells were made competent by treatment with $\mathrm{CaCl}_{2}$, and the ligated mix was used for transformation of the cells. The cells were transferred on LB-AMP plates containing $100 \mathrm{mg} / \mathrm{L}$ of ampicillin (AMP), the inducer isopropyl thiogalactoside, and the substrate $\beta$-D-galactoside to screen the transformants. Plasmids were isolated from the transformed colonies and run on the agarose gel along with control, and retardation checks were performed to observe the mobility difference. Finally, the clones were subjected to restriction digestion with EcoR1 and checked for insert release as a part of the clone confirmation.

\section{Screening for lipase gene expression}

Since the expression of Bacillus lipase in E. coli may or may not be extracellular, all the transformed colonies were screened by checking extracellular as well as intracellular lipase activity using tributyrin agar (TBA) plates. Each of the transformed colonies were grown for $48 \mathrm{~h}$ in LB broth and the cells were harvested by centrifugation at $6000 \mathrm{xg}$ for $10 \mathrm{~min}$. The supernatant was used as the extracellular extract, and the pellet, upon sonication, was used as the intracellular extract. The extract, $50 \mu \mathrm{L}$, was added to wells cut in TBA plates and zones of clearance were observed.

\section{Sequencing and analysis of the lipase-encoding gene}

The best lipase producing clone was chosen for DNA isolation and purification. It was sequenced using M13 primers in an ABI prism 3100 Genetic Analyzer (Applied Biosystem). The forward and reverse sequences were aligned using ClustalX 1.83 and submitted to the NCBI Genbank database. The nucleotide sequence was converted to the corresponding peptide sequence (EMBOSS Transeq), and Protein Blast was used to perform sequence similarity searches in the NCBI protein database. The closest matches were considered, and the phylogenetic tree was constructed using the neighbor-joining method (Kimura, 1980). Smith-Waterman algorithm was used to calculate the local alignment with other lipase sequences in the database. EMBOSS Pepstats program was applied to calculate the molecular weight and isoelectric point for the predicted peptide. 


\section{Purification of the recombinant lipase from E. coli}

The LB medium was inoculated with $2 \%(\mathrm{v} / \mathrm{v})$ seed culture of the $E$. coli clone (overnight grown, cell density $32 \times 10^{6} \mathrm{cfu} / \mathrm{mL}$ ) and cultivated for $48 \mathrm{~h}$ at $37^{\circ} \mathrm{C}$. The cells were harvested by centrifugation and the intracellular lipase was released by sonication. It was purified using the Phenyl Sepharose CL-4B matrix. The column was equilibrated with $10 \mathrm{mM}$ potassium-phosphate buffer $\mathrm{pH}$ 7.4, containing $1 \mathrm{mM}$ ethylene diamine tetra acetic acid (EDTA), $1 \mathrm{M}\left(\mathrm{NH}_{4}\right)_{2} \mathrm{SO}_{4}$, and $7 \mathrm{mM}$ 2-mercaptoethanol. The sample was loaded, the column was washed, and then step elution was performed using a buffer containing decreasing salt concentrations $(0.6,0.3$, and $0 \mathrm{M})$. About $2 \mathrm{~mL}$ fractions were collected and assayed for lipase activity using TBA plate assay and $p$-NPP spectrophotometric assay (Winkler and Stuckmann, 1979).

The substrate solution for $p$-NPP assay was prepared by adding solution A (30 mg of $p$-NPP in $10 \mathrm{~mL}$ of isopropanol) into solution $\mathrm{B}(0.1 \mathrm{~g}$ acacia gum and $100 \mathrm{~mL}$ phosphate buffer, $\mathrm{pH}$ 7). The reaction mixture containing $1.0 \mathrm{~mL}$ of the substrate solution and $0.3 \mathrm{~mL}$ of lipase enzyme was incubated at $30{ }^{\circ} \mathrm{C}$ for $15 \mathrm{~min}$. Triton $\mathrm{X}-100$ $(50 \mu \mathrm{L})$ was added at the end of the reaction to obtain a clear solution. The absorbance was measured using a spectrophotometer (Shimadzu, UV-1800) at $410 \mathrm{~nm}$, against an enzyme-free blank. The molar extinction coefficient $0.0146 \mu \mathrm{M}^{-1} \mathrm{~cm}^{-1}$ was used. One unit of lipase activity is defined as micromoles of $p$-nitrophenol released per minute under the assay conditions. All activity assays were performed in triplicates, and the values given represent the mean.

The pooled fractions obtained from the CL-4B column were applied onto ion exchange column packed with phosphocellulose PC-11. This column was equilibrated using $10 \mathrm{mM}$ phosphate buffer $\mathrm{pH} 7.4$, containing $1 \mathrm{mM}$ EDTA, $50 \mathrm{mM} \mathrm{KCl}$, and $7 \mathrm{mM}$ 2-mercaptoethanol. The sample was loaded, and after washing the column, it was eluted using a gradient of low to high salt buffer (equilibration buffer containing 0-1.0 M KCl). The fractions were assayed for lipase activity as described earlier. The samples obtained from each stage of the purification process were also subjected to sodium dodecyl sulfate-polyacrylamide gel electrophoresis (SDS-PAGE) on a 12\% separating gel (Laemmli, 1970) to check the purity and to estimate the molecular weight. The protein bands were visualized by Coomassie Brilliant Blue R-250 staining.

\section{Characterization of the recombinant lipase}

\section{Effect of $\mathrm{pH}$ on the lipase activity and stability}

The effect of reaction $\mathrm{pH}$ on the activity of recombinant PS-35 lipase was inferred by performing the enzyme assay at different $\mathrm{pH}$ values (5-10). $\mathrm{pH}$ stability of the enzyme was assessed by preincubating the enzyme for $1 \mathrm{~h}$ in buffers having a $\mathrm{pH}$ range of 6-10. Citrate, phosphate, and
Tris- $\mathrm{HCl}$ buffers $(100 \mathrm{mM})$ were used for the acidic, neutral, and alkaline ranges, respectively. The residual activity was then checked under standard assay conditions.

\section{Effect of temperature on the lipase activity, thermostability,} and half-life

The effect of reaction temperature on the activity of recombinant PS-35 lipase was inferred by performing the enzyme assay at different temperatures $\left(20{ }^{\circ} \mathrm{C}-60{ }^{\circ} \mathrm{C}\right)$. Thermostability was studied by preincubating the enzyme at temperatures ranging from $40{ }^{\circ} \mathrm{C}$ to $80{ }^{\circ} \mathrm{C}$ for $1 \mathrm{~h}$ and assaying the residual activity as mentioned earlier. The halflife of the enzyme was determined by incubating the sample at 50,60 , and $70{ }^{\circ} \mathrm{C}$ and assaying the residual activity at regular intervals for up to $6 \mathrm{~h}$.

\section{Effect of metal ions on the lipase activity}

Salts of $\mathrm{K}^{+}, \mathrm{Fe}^{3+}, \mathrm{Hg}^{2+}, \mathrm{Mg}^{2+}, \mathrm{Al}^{3+}, \mathrm{Co}^{2+}, \mathrm{Mn}^{2+}, \mathrm{Zn}^{2+}$, and $\mathrm{Na}^{+}$were separately added to the assay mixture at final concentrations of 1.0 and $5.0 \mathrm{mM}$, and the enzyme activity was monitored under standard conditions.

\section{Effect of organic solvents and chemical modifiers on the lipase activity}

The organic solvents, such as ethanol, methanol, $n$-hexane, and toluene, were individually added to the reaction mixture at concentrations of $10 \%, 20 \%$, and $30 \% \mathrm{v} / \mathrm{v}$, and the lipase activity was determined under standard assay conditions. Various chemical modifiers such as diethyl pyrocarbonate (DEPC), phenyl methane sulfonyl fluoride (PMSF), EDTA, dithiothreitol (DTT), and SDS were added at concentrations of 2,5 and $10 \mathrm{mM}$ to the enzyme sample, and the assay was performed under standard conditions. The sample without any additives was taken as control.

\section{Determination of Michaelis-Menten kinetics}

The kinetic parameters $K_{\mathrm{m}}$ and $V_{\max }$ were determined using the Lineweaver-Burk plot, by varying the concentration of the $p$-NPP substrate from 3.0 to $24.0 \mathrm{mM}$.

\section{Substrate preference of lipase}

The ability of the enzyme to cleave other p-nitrophenyl esters, such as p-nitrophenyl laurate, p-nitrophenyl caprylate, p-nitrophenyl formate, and p-nitrophenyl acetate, was compared with $p$-NPP, and the relative activities were calculated. These substrates were added at a concentration of $20 \mathrm{mM}$.

\section{Results and Discussion}

\section{Cloning, expression, and sequencing of the lipase-encoding gene}

In TBA plate assay, among cultures of the transformed colonies screened for lipase activity, clones 4 and 16 showed clearance zones, and the zone of clone 4 was most prominent (result not shown). These cultures were 
thus taken as positive for lipase activity. Quantification of enzyme activity of the clones using $p$-NPP assay resulted in 30.21 and $09.86 \mathrm{U} / \mathrm{mL}$ of lipase activities for clones 4 and 6 , respectively. This activity is higher than that reported in the literature for several Bacillus spp., whose wild-type strains generally display lower activity (Kumar et al., 2005; Olusesan et al., 2011). This clone, therefore, was selected for sequencing.

\section{Sequence analysis}

The nucleotide sequence of the lipase gene was submitted to the NCBI Genbank database (accession no. KM225297). The sequence codes for a 214 amino acid long peptide (accession no. AIW00097.1). The protein sequence, upon blastp search, revealed strong similarity (up to $98 \%$ ) to other sequences in the database. The dendrogram depicting sequence relationship between PS-35 lipase expressed in clone 4 (henceforth referred to as C-4 lipase) and other lipase sequences in the database is given in Figure 1.

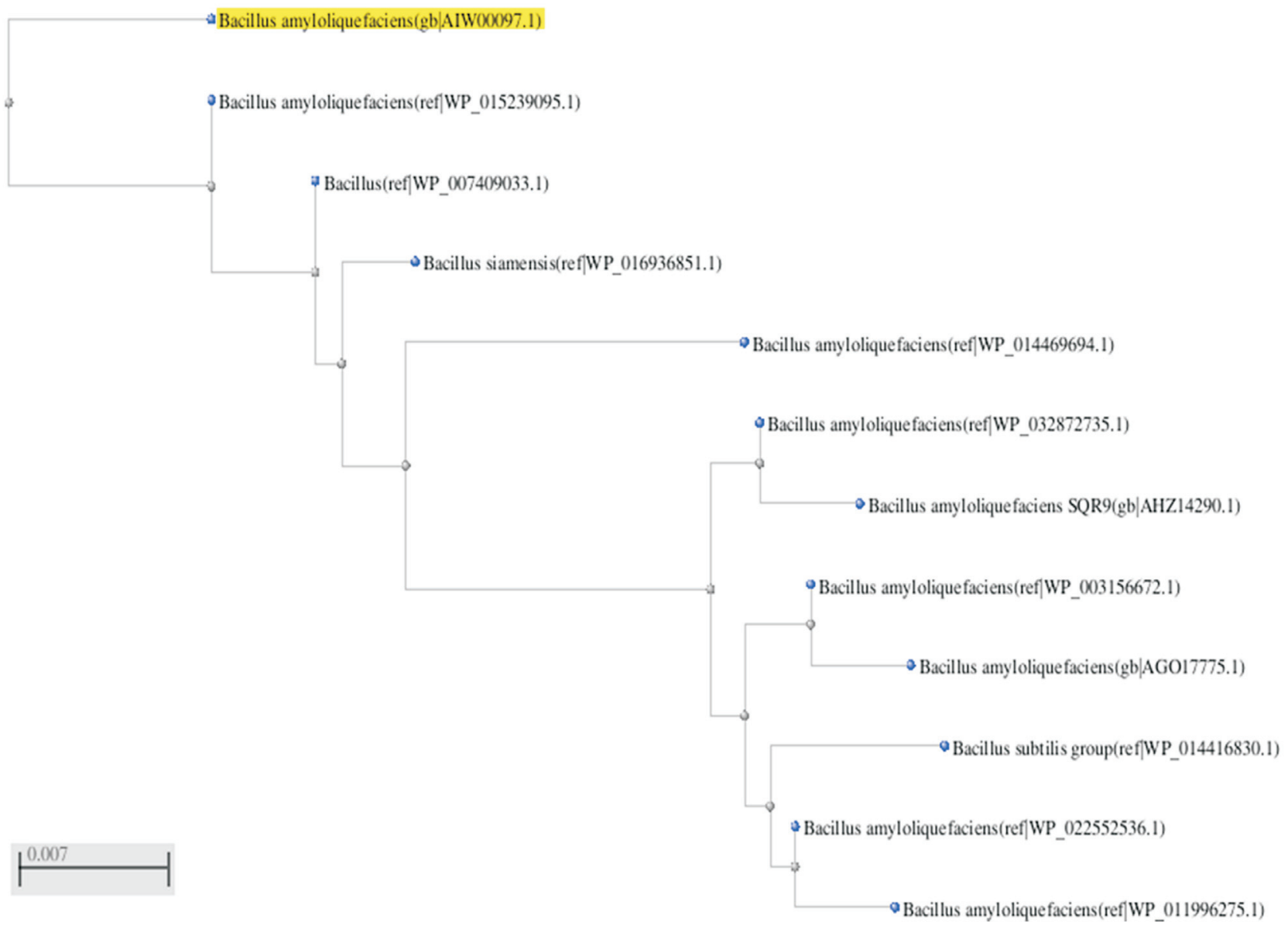

Bacterial lipases have been classified into families 1-6 (Jaeger et al., 1999). Family 1 has been subclassified into six families; Bacillus lipases belong to either subfamily 1.4 or 1.5 based on similarities of nucleotide sequences and molecular weight. Subfamily 1.4 comprises of lipases from mesophilic, low molecular weight Bacillus spp., which share a high degree of sequence homology. Furthermore, in subfamily 1.4, the pentapeptide sequence Gly-X-Ser-X-Gly flanking the catalytic serine residue is replaced by the Ala-X-Ser-X-Gly. This conserved motif was also observed in our lipase.

Aligning the peptide sequence of C-4 lipase with a triacylglycerol lipase (accession no. WP 015239095.1) in the database showed $98.1 \%$ identity, $98 . \overline{6 \%}$ similarity, and $0 \%$ gaps. The alignment between these two sequences is shown in Figure 2. It could be observed that C-4 lipase displays amino acid differences from the closest matching database sequence at positions 70, 90, 164 and 195, where the $\mathrm{Y}, \mathrm{N}, \mathrm{S}$, and $\mathrm{N}$ residues have been replaced with $\mathrm{A}, \mathrm{T}, \mathrm{A}$, and $\mathrm{M}$, respectively. These variations in the primary structure of the enzyme may result in conformational changes,

Figure 1 - Phylogenetic tree of C-4 lipase. M13 primers were used for nucleotide sequencing, and the forward and reverse sequences were aligned using ClustalX 1.83. Emboss Transeq was used to convert it to the corresponding peptide sequence, and Blastp was performed. The neighbor-joining method was used for construction of the phylogenetic tree. 


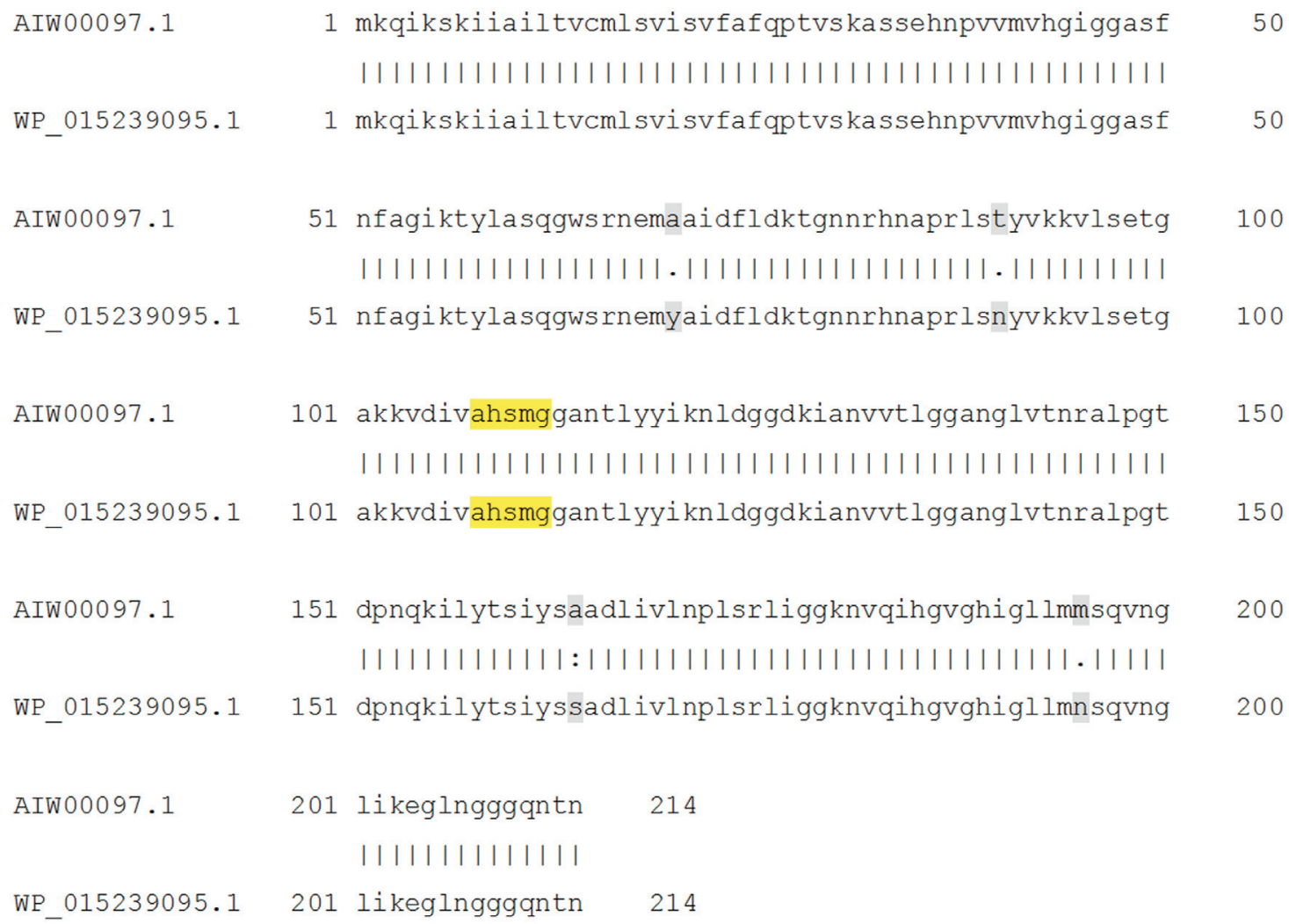

AIW00097.1

WP_015239095.1

214

214

Figure 2 - Pairwise sequence alignment of C-4 lipase (AIW00097.1). The closest matching database sequence (WP_015239095.1) was used to obtain the alignment. The conserved lipase motifs and the regions of mismatch between the two sequences are highlighted.

which in turn may reflect on its functions, though this aspect warrants further study. The molecular weight of the predicted peptide was calculated to be $22.6 \mathrm{kDa}$ and the isoelectric point to be 10.27 . The peptide showed $0.947 \mathrm{im}$ probability of being expressed in inclusion bodies.

\section{Purification of recombinant lipase from E. coli}

SDS-PAGE of crude and purified lipase preparations is presented in Figure 3. The monomeric lipase appeared as single band around $29 \mathrm{kDa}$. Similarly, the purified recombinant $B$. licheniformis lipase appeared as a single band around $25 \mathrm{kDa}$ (Nthangeni et al., 2001). Comparable mo- lecular weights have also been reported from other studies. For instance, a recombinant $B$. subtilis lipase had demonstrated the band of $24 \mathrm{kDa}$ (Ma et al., 2006). The purification chart for the recombinant lipase is summarized in Table 1. The lipase was purified 19.41-fold with a yield of $9.7 \%$. In an earlier study, a recombinant $B$. subtilis lipase was purified approximately 19.7 -fold by employing ion exchange and gel filtration chromatography (Ma et al., 2006).

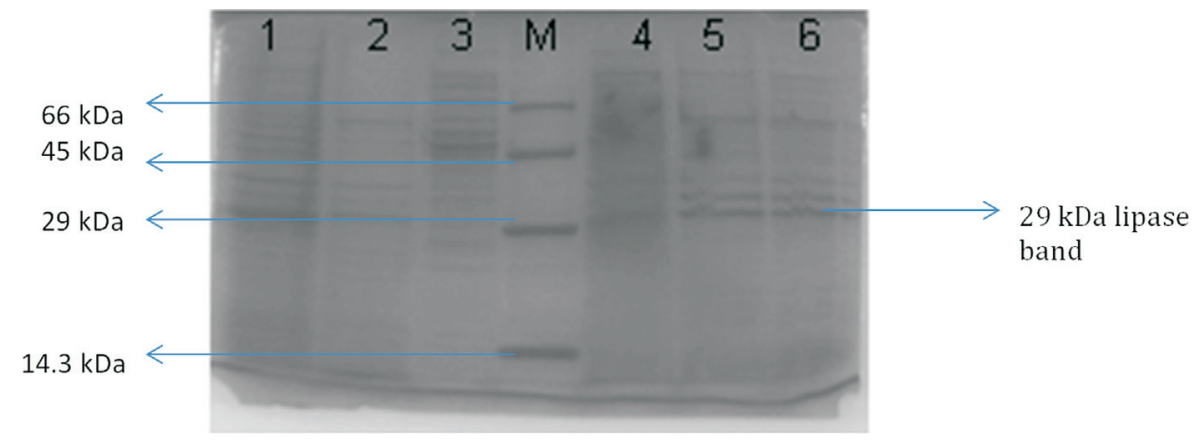

Figure 3 - SDS-PAGE of crude and purified lipase preparations. Lane M: molecular weight markers, 1 and 2: crude samples, 3 and 4: load samples, 5 and 6: purified lipase (pool I) from the phosphocellulose column, 30 and $50 \mu \mathrm{L}$ samples. 
Table 1 - Purification chart for the recombinant lipase C-4.

\begin{tabular}{lcccccc}
\hline Sample & Total volume $(\mathrm{mL})$ & Total protein $(\mathrm{mg})$ & Lipase activity $(\mathrm{U})$ & Specific activity & Fold purification & Yield $(\%)$ \\
\hline Crude* & 100 & 10 & 240 & 24 & 1 & 100 \\
CL-4B* & 4 & 0.4 & 54.6 & 136.5 & 5.68 & 22.75 \\
PC-11* & 1.2 & 0.05 & 23.3 & 466 & 19.41 & 9.7 \\
\hline
\end{tabular}

Crude: intracellular enzyme extract after sonication; CL-4B: pooled active fractions from the Phenyl Sepharose column; PC-11: pooled active fractions from the phosphocellulose column.

\section{Characterization of the recombinant lipase}

\section{Effect of $\mathrm{pH}$ on the lipase activity and stability}

Optimum C-4 lipase activity was observed at $\mathrm{pH}$ 8.0, which was $28.81 \mathrm{U} / \mathrm{mL}$ (Figure 4). Considerable residual activity was observed in the $\mathrm{pH}$ range of $6.5-8.5$, which dropped drastically beyond the range. The enzyme showed maximum stability at $\mathrm{pH}$ up to 8.0. After that, there was slight loss of the activity, which reduced to $33 \%$ upon exposure to $\mathrm{pH} 10$ (Figure 4). A recombinant B. subtilis lipase had shown an optimum $\mathrm{pH}$ of 8.5 and considerable stability in the range of 6.5-10.0 (Quyen et al., 2003).

\section{Effect of temperature on the lipase activity, thermostability, and half-life}

The maximum activity of $29.13 \mathrm{U} / \mathrm{mL}$ was observed at an assay temperature of $40{ }^{\circ} \mathrm{C}$ (Figure 5). The activity was reasonably maintained up to a temperature of $50{ }^{\circ} \mathrm{C}$, but above that it decreased to $5 \mathrm{U} / \mathrm{mL}$. Preincubation of the enzyme at temperatures greater than the optimal temperature led to the loss of enzyme activity. More than $50 \%$ of the activity was lost at temperatures above $55^{\circ} \mathrm{C}$ (Figure 5).

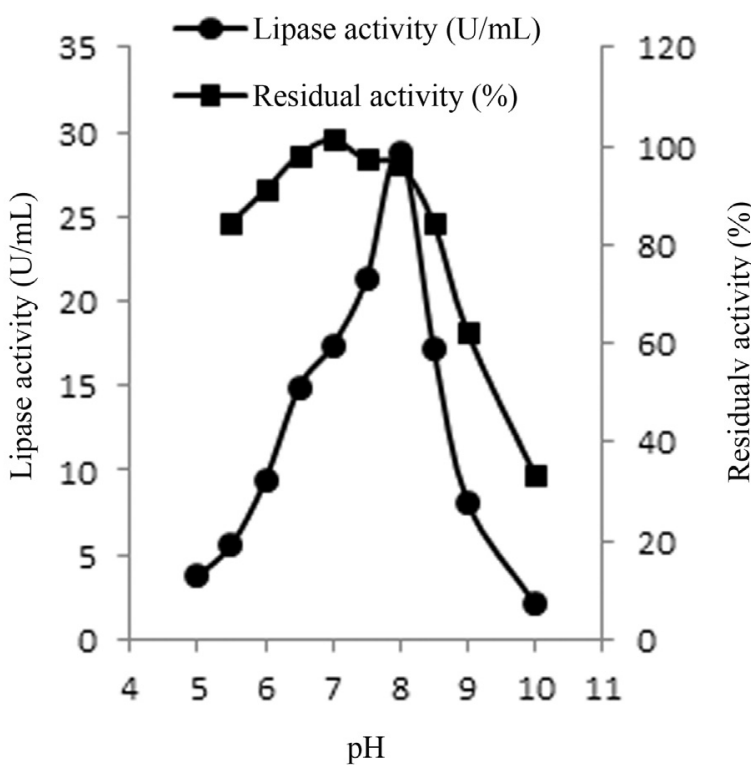

Figure 4 - Effect of $\mathrm{pH}$ on the lipase activity and stability. Citrate, phosphate, and Tris- $\mathrm{HCl}$ buffers $(100 \mathrm{mM})$ were used for the acidic, neutral, and alkaline ranges, respectively. The residual activity was checked under standard assay conditions of $30^{\circ} \mathrm{C}$ and $15 \mathrm{~min}$ incubation.
The recombinant lipase from $B$. subtilis displayed maximum activity at $43{ }^{\circ} \mathrm{C}$ with loss of stability at temperatures above $45^{\circ} \mathrm{C}$ (Ma et al., 2006). The half-lives of C-4 lipase were $2.0,1.0$, and $0.5 \mathrm{~h}$ at $50^{\circ} \mathrm{C}, 60^{\circ} \mathrm{C}$, and $70^{\circ} \mathrm{C}$, respectively (Figure 6). B. coagulans BTS-3 lipase had been reported to possess half-lives of 2.0 and $0.5 \mathrm{~h}$ at $55^{\circ} \mathrm{C}$ and $60{ }^{\circ} \mathrm{C}$, respectively (Kumar et al., 2005).

\section{Effect of metal ions on the lipase activity}

Metal ions showed variable effects on the activity of C-4 lipase, with only marginal enhancement or inhibition in most cases at a concentration of $1.0 \mathrm{mM}$ (Table 2 ). $\mathrm{K}^{+}$and $\mathrm{Fe}^{3+}$ ions $(5.0 \mathrm{mM})$ resulted in $42 \%$ and $28 \%$ increase in the activity, respectively. $\mathrm{Mg}^{2+}, \mathrm{Mn}^{2+}, \mathrm{Zn}^{2+}, \mathrm{Na}^{+}$, and even $\mathrm{Ca}^{2+}$ boosted the enzyme activity at a very low level. $\mathrm{Al}^{3+}$ and $\mathrm{Hg}^{2+}$ significantly inhibited enzyme activity (79\% and 58\% residual activity), especially at higher concentrations. Lipase from B. subtilis NS-8 showed slight enhancement in activity upon treatment with $\mathrm{Mg}^{2+}$, no significant change in the presence of $\mathrm{Ca}^{2+}$, and marked inhibition in the presence of other metal ions (Olusesan et al., 2011). Interestingly, we did not observe any effect of $\mathrm{Ca}^{2+}$ on the lipase activity, though most of the other lipases showed enhancement in the activity in the presence of $\mathrm{Ca}^{2+}$ ions (Nawani and Kaur, 2007).

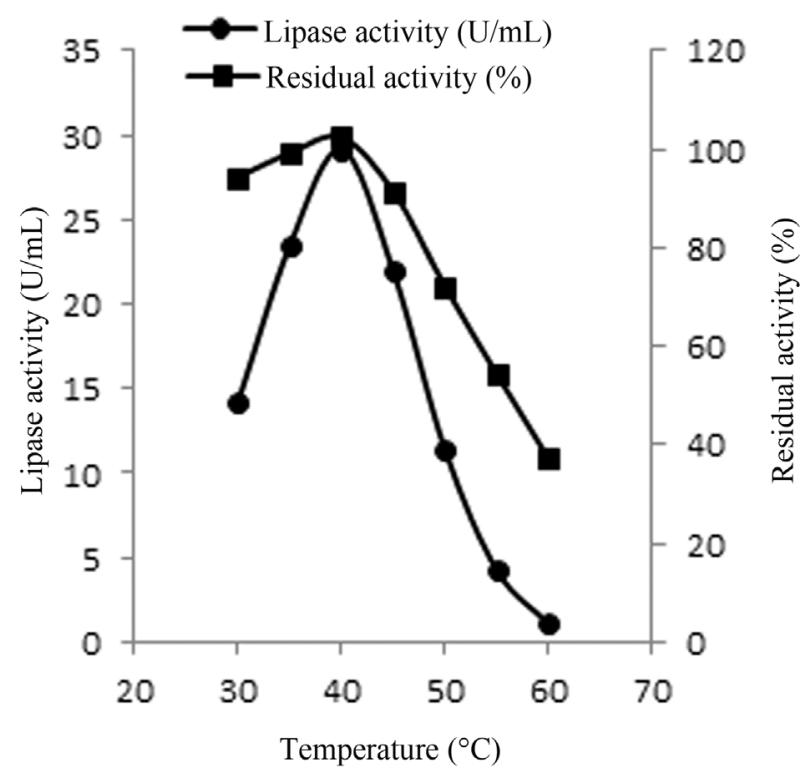

Figure 5 - Effect of temperature on the lipase activity and stability. 


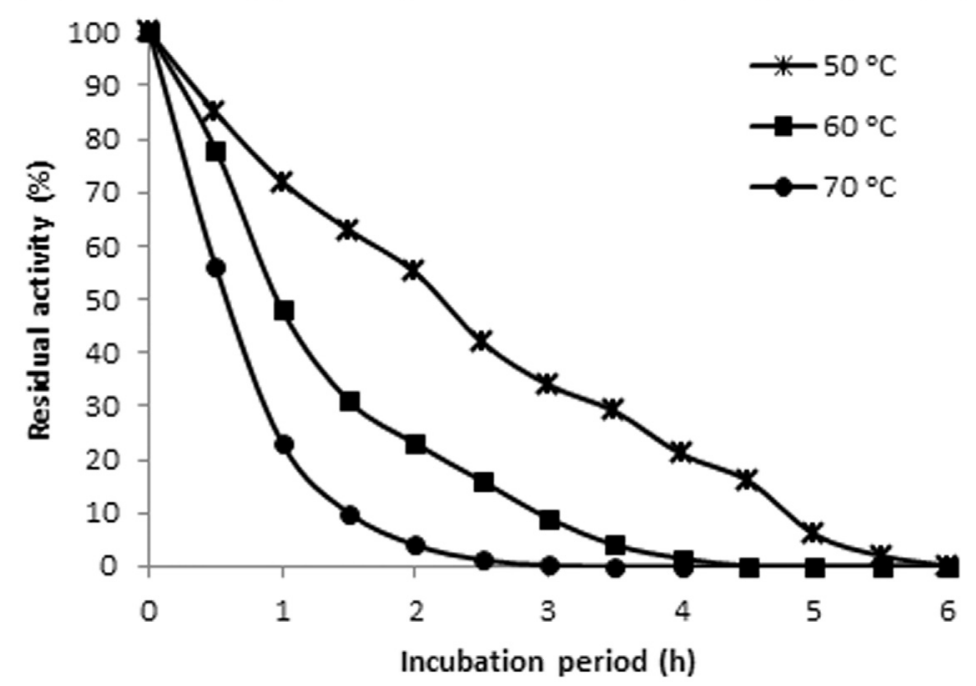

Figure 6 - Half-life of lipase.

Effect of organic solvents and chemical modifiers on the lipase activity

Various organic solvents affected the activity of C-4 lipase (Table 3 ). The catalytic activity was retained or slightly augmented in the presence of water-immiscible organic solvents. $n$-Hexane and toluene resulted in $32 \%$ and $28 \%$ increase in the activity at a concentration of $30 \%$. The water miscible solvents, particularly methanol, hampered the enzyme activity (58\% residual activity) at higher concentrations. Contrary to our observation, a recombinant $\mathrm{Ba}$ cillus thermocatenulatus BTL2 lipase was inhibited by the organic solvents, such as methanol, acetone, and 2-propanol, at the same 30\% concentration (Quyen et al., 2003).

Among the tested chemical modifiers (Table 3), DTT alone did not show any inhibitory effect and in fact stimulated the enzyme activity slightly. All other compounds (SDS, EDTA, DEPC, and PMSF) inhibited the activity to

Table 2 - Effect of metal ions on the lipase activity.

\begin{tabular}{lcc}
\hline Metal ions & \multicolumn{2}{c}{ Relative activity (\%) } \\
\cline { 2 - 3 } & $1.0 \mathrm{mM}$ & $5.0 \mathrm{mM}$ \\
\hline $\mathrm{K}^{+}$ & 123 & 142 \\
$\mathrm{Fe}^{3+}$ & 112 & 128 \\
$\mathrm{Hg}^{2+}$ & 86 & 58 \\
$\mathrm{Mg}^{2+}$ & 103 & 109 \\
$\mathrm{Al}^{3+}$ & 94 & 79 \\
$\mathrm{Ca}^{2+}$ & 101 & 103 \\
$\mathrm{Mn}^{2+}$ & 106 & 112 \\
$\mathrm{Zn}^{2+}$ & 108 & 124 \\
$\mathrm{Na}^{+}$ & 101 & 104 \\
\hline
\end{tabular}

varying extents. The residual activity was always greater than $50 \%$ when these compounds were present at low concentrations. A more pronounced loss of activity was witnessed at high concentrations, with EDTA leading to $75 \%$ activity inhibition at $10 \mathrm{mM}$ concentration. A thermophilic lipase from Bacillus sp. showed retention of activity in the presence of DTT. The residual activity upon treatments with $100 \mathrm{mM}$ PMSF and EDTA was $35.1 \%$ and $36.8 \%$, respectively (Nawani and Kaur, 2007). Lipase from Aneurinibacillus thermoaerophilus $\mathrm{HZ}$ showed 41\% residual activity in the presence of PMSF, 53\% in the presence of DTT, and $73 \%$ in the presence of EDTA. All compounds were studied at a concentration of $5 \mathrm{mM}$ (Masomian et al., 2013).

Table 3 - Effect of organic solvents and chemical modifiers on the lipase activity.

\begin{tabular}{lccc}
\hline \multirow{2}{*}{$\begin{array}{l}\text { Additives (organic solvents/ } \\
\text { chemical modifiers*) }\end{array}$} & \multicolumn{3}{c}{ Relative activity (\%) } \\
\cline { 2 - 4 } & $10 \%$ & $20 \%$ & $30 \%$ \\
\hline Ethanol & 91 & 83 & 69 \\
Methanol & 85 & 72 & 58 \\
n-hexane & 112 & 123 & 132 \\
Toluene & 109 & 118 & 128 \\
& $2 \mathrm{mM}$ & $5 \mathrm{mM}$ & $10 \mathrm{mM}$ \\
DTT & 102 & 108 & 112 \\
SDS & 78 & 56 & 35 \\
EDTA & 65 & 42 & 25 \\
DEPC & 92 & 83 & 76 \\
PMSF & 83 & 68 & 43 \\
\hline
\end{tabular}

The chemical modifiers used were diethyl pyrocarbonate (DEPC), phenyl methane sulfonyl fluoride (PMSF), ethylene diamine tetra acetic acid (EDTA), dithiothreitol (DTT), and sodium dodecyl sulfate (SDS). 


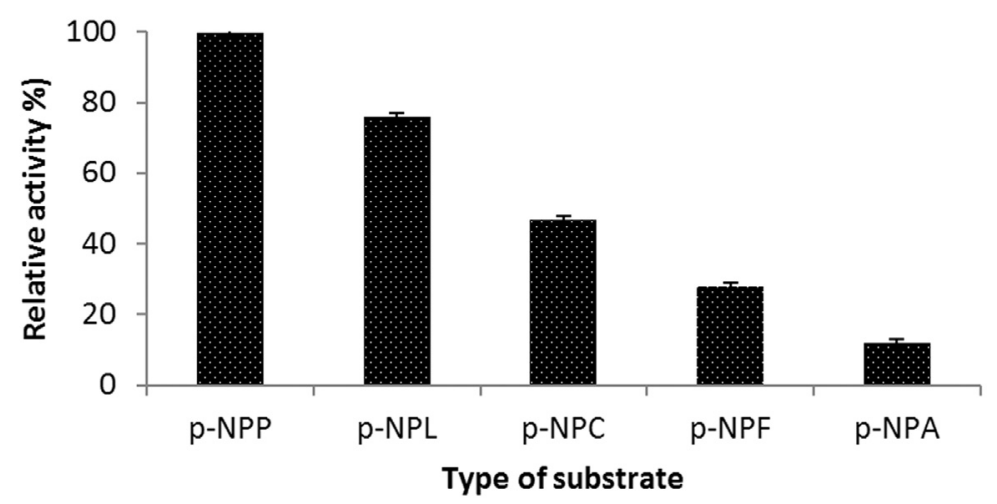

Figure 7 - Substrate specificity of the lipase. The substrates used were $p$-nitrophenyl palmitate ( $p$-NPP), $p$-nitrophenyl laurate ( $p$-NPL), $p$-nitrophenyl caprylate ( $p$-NPC), $p$-nitrophenyl formate ( $p$-NPF), and $p$-nitrophenyl acetate ( $p$-NPA).

\section{Determination of Michaelis-Menten kinetics}

The kinetic parameters $K_{\mathrm{m}}$ and $V_{\max }$ of the purified recombinant lipase were determined as $4.345 \mathrm{mM}$ and $38.46 \mu \mathrm{M} / \mathrm{mg} / \mathrm{min}$, respectively, from the Lineweaver Burk plot (not shown). The lipase from $B$. licheniformis showed $K_{\mathrm{m}} 29 \mathrm{mM}$ and $V_{\max } 0.64 \mathrm{mM} / \mathrm{mg} / \mathrm{min}$ (Chakraborty and Raj, 2008).

\section{Substrate specificity of the lipase}

C-4 lipase showed a preference for long-chain $p$-nitrophenyl esters. The activity was maximum for $p$-NPP (C-16) followed by $p$-NPL (C-12). It showed only lesser hydrolytic ability toward the short-chain esters (Figure 7). This proves that the enzyme is a true lipase and acts at the oil-water interface of water-insoluble long-chain fatty acid esters (Bjorkling et al., 1991; Gupta et al., 2004). The lipase from B. coagulans BTS-3 also showed a similar preference (Kumar et al., 2005). In contrast, an esterase from thermophilic Bacillus sp. showed no hydrolytic activity toward $p$-NPP and only negligible activity toward $p$-NPL (Ateslier and Metin, 2006), thereby highlighting the difference between esterases and true lipases.

\section{Conclusions}

This study has addressed a novel lipase enzyme and encoding gene from the bacterium $B$. amyloliquefaciens. As per the best of our knowledge, there is no earlier report on the lipase, particularly at molecular level, from this bacterial source. The lipase gene from strain PS35 has been cloned and expressed in E. coli DH5 $\alpha$ cells. The predicted peptide showed strong identity with other lipases; though certain key amino acids were found to be substituted in comparison with other lipases in the NCBI protein database. This aspect needs further investigation. The recombinant protein is successfully purified and molecular weight is determined. The enzyme works best under mesophilic and mild alkaline conditions. It has also exhibited good tolerance to nonpolar organic solvents, a characteristic that is of significance in catalyzing synthetic reactions in wa- ter-restricted environments. Other attractive properties of the enzyme include stability in the presence of chemical modifiers such as DTT and certain metal ions. These findings indicate that the enzyme offers scope for a wide range of industrial applications including biodiesel production and polymer synthesis, which could be explored in further studies.

\section{References}

Ateslier ZBB, Metin K (2006) Production and partial characterization of a novel thermostable esterase from a thermophilic Bacillus sp. Enzyme Microb Technol 38:628-635.

Bjorkling F, Godtfredsen SE, Kirk O (1991) The future impact of industrial lipases. TIBTECH 9:360-363.

Chakraborty K, Raj P (2008) An extra-cellular alkaline metallolipase from Bacillus licheniformis MTCC 6824: Purification and biochemical characterization. Food Chem 109:727-736.

Chen L, Coolbear T, Daniela RM (2004) Characteristics of proteinases and lipases produced by seven Bacillus sp. isolated from milk powder production lines. Int Dairy J 14:495-504.

Chen S, Qian L, Shi B (2007) Purification and properties of enantioselective lipase from a newly isolated Bacillus cereus C71. Process Biochem 42:988-994.

Gupta R, Gupta N, Rathi P (2004) Bacterial lipases: an overview of production, purification and biochemical properties. Appl Microbiol Biotechnol 64:763-781.

Hassan F, Shah AA, Hameed A (2006) Industrial applications of microbial lipases. Enzyme Microb Technol 39:235-245.

Hirose K, Sano I, Shioda M et al. (2000) Proteome analysis of Bacillus subtilis extracellular proteins: a two-dimensional protein electrophoretic study. Microbiology 146:65-75.

Jaeger KE, Dijkstra BW, Reetz MT (1999) Bacterial biocatalysts: molecular biology, three-dimensional structures, and biotechnological applications of lipases. Annu Rev Microbiol 53:315-351.

Kambourova M, Kirilova N, Mandeva R et al. (2003) Purification and properties of thermostable lipase from a thermophilic Bacillus stearothermophilus MC 7. J Mol Catal B: Enzym 22:307-313. 
Kimura M (1980) A simple method for estimating evolutionary rates of base substitutions through comparative studies of nucleotide sequences. J Mol Evol 16:111-120.

Kumar S, Kikon K, Upadhyay A et al. (2005) Production, purification, and characterization of lipase from thermophilic and alkaliphilic Bacillus coagulans BTS-3. Protein Expr Purif 41:38-44

Laemmli UK (1970) Cleavage of structural proteins during the assembly of the head of bacteriophage T4. Nature 227:680-685.

Lee DW, Kim HW, Lee KW et al. (2001) Purification and characterization of two distinct thermostable lipases from the Gram-positive thermophilic bacterium Bacillus thermoleovorans ID-1. Enzyme Microb Technol 29:363371 .

Ma J, Zhang Z, Wang B et al. (2006) Overexpression and characterization of a lipase from Bacillus subtilis. Protein Expres Purif 45:22-29.

Masomian M, Rahman RNZRA, Salleh AB et al. (2013) A new thermostable and organic solvent-tolerant lipase from Aneurinibacillus thermoaerophilus strain HZ. Process Biochem 48:169-175.

Nawani N, Kaur J (2007) Studies on lipolytic isoenzymes from a thermophilic Bacillus sp.: Production, purification and biochemical characterization. Enzyme Microb Technol 40:881-887.

Nthangeni MB, Patterton HG, Tonder AV et al. (2001) Overexpression and properties of a purified recombinant Bacillus licheniformis lipase: a comparative report on Bacillus lipases. Enzyme Microb Technol 28:705-712.
Olusesan AK, Azura LK, Forghani B et al. (2011) Purification, characterization and thermal inactivation kinetics of a nonregioselective thermostable lipase from a genotypically identified extremophilic Bacillus subtilis NS 8. New Biotechnol 28:138-745.

Quyen DT, Schmidt-Dannert C, Rolf D (2003) High-level expression of a lipase from Bacillus thermocatenulatus BTL2 in Pichia pastoris and some properties of the recombinant lipase. Protein Expres Purif 28:102-110.

Sabri S, Rahman RNZRA, Leow TC et al. (2009) Secretory expression and characterization of a highly $\mathrm{Ca}^{2+}$ - activated thermostable L2 lipase. Protein Expr Purif 68:161-166.

Sambrook J, Fritsch EF, Maniatis T (1989) Molecular cloning: a laboratory manual. $2^{\text {nd }}$ ed. Cold Springs Harbor Laboratory, New York.

Sambrook J, Russell DW (2001) Molecular cloning: a laboratory manual. $3^{\text {rd }}$ ed. Cold Springs Harbor Laboratory, New York.

Sunna A, Hunter L, Hutton CA et al. (2002) Biochemical characterization of a recombinant thermoalkalophilic lipase and assessment of its substrate enantioselectivity. Enzyme Microb Technol 31:472-476.

Tjalsma H, Bolhuis A, Jongbloed JDH et al. (2000) Signal peptide-dependent protein transport in Bacillus subtilis: a genome-based survey of the secretome. Microbiol Mol Biol Rev 64:515-547.

Winkler UK, Stuckmann M (1979) Glycogen, hyaluronate and some other polysaccharides greatly enhance the formation of exolipase by Serratia marcescens. J Bacteriol 138:663-670.

Associate Editor: Gisele Monteiro de Souza

All the content of the journal, except where otherwise noted, is licensed under a Creative Commons License CC BY-NC. 